\title{
Regulating genetically modified crops in view of environmental risks
}

Citation for published version (APA):

Liu, A. (2019). Regulating genetically modified crops in view of environmental risks: China's implementation of international obligations. [Doctoral Thesis, Maastricht University]. ProefschriftMaken Maastricht. https://doi.org/10.26481/dis.20190222al

Document status and date:

Published: 01/01/2019

DOI:

10.26481/dis.20190222al

Document Version:

Publisher's PDF, also known as Version of record

\section{Please check the document version of this publication:}

- A submitted manuscript is the version of the article upon submission and before peer-review. There can be important differences between the submitted version and the official published version of record.

People interested in the research are advised to contact the author for the final version of the publication, or visit the DOI to the publisher's website.

- The final author version and the galley proof are versions of the publication after peer review.

- The final published version features the final layout of the paper including the volume, issue and page numbers.

Link to publication

\footnotetext{
General rights rights.

- You may freely distribute the URL identifying the publication in the public portal. please follow below link for the End User Agreement:

www.umlib.nl/taverne-license

Take down policy

If you believe that this document breaches copyright please contact us at:

repository@maastrichtuniversity.nl

providing details and we will investigate your claim.
}

Copyright and moral rights for the publications made accessible in the public portal are retained by the authors and/or other copyright owners and it is a condition of accessing publications that users recognise and abide by the legal requirements associated with these

- Users may download and print one copy of any publication from the public portal for the purpose of private study or research.

- You may not further distribute the material or use it for any profit-making activity or commercial gain

If the publication is distributed under the terms of Article $25 \mathrm{fa}$ of the Dutch Copyright Act, indicated by the "Taverne" license above, 


\section{SUMMARY}

GM crops may cause environmental risks. Cultivation of GM crops is a key process in causing environmental risks. Environmental risks that may be caused by GM crops need to be assessed and managed on a case-by-case basis in accordance with international law and Chinese law. This thesis discussed three questions: 1 ) What are the international obligations of China in relation to addressing environmental risks that may be caused by the cultivation of GM crops and related activities? 2) What is the regulatory framework and the institutional structure addressing environmental risks that may be caused by the cultivation of GM crops and related activities in China? and 3) How has China implemented its international obligations in this regard?

Chapter One analysed the research background, research questions, methodology, and the structure of this thesis. The scientific literature has identified different sources of environmental risks that may be caused by the cultivation of GM crops and related activities. This thesis used the legal doctrinal method to discuss the regulatory approaches of international law and Chinese law for dealing with environmental risks that may be caused by the cultivation of GM crops and related activities.

Chapter Two analysed the first main research question, which contains two subquestions: (a) To what extent have environmental risks that may be caused by the cultivation of GM crops and related activities been regulated by legally binding and potentially legally binding international instruments? And (b) Is China subject to any international obligation to address environmental risks that may be caused by the cultivation of GM crops and related activities? If such obligations exist, what are the requirements they impose? There are three legally binding international instruments that deal with adverse effects on the conservation and sustainable use of biodiversity resulting from GM crops: the Convention on Biological Diversity, the Cartagena Protocol on Biosafety and the Nagoya-Kuala Lumpur Supplementary Protocol. These three international instruments have the aim of ensuring the safe use of LMOs. They are applicable to activities that may have adverse effects on the conservation and sustainable use of biodiversity, taking also into account risks to human health, and especially focusing on transboundary movements. Living GM crops are one category of LMOs, and therefore the cultivation of GM crops relates to activities regulated by the three instruments.

China is a party to the Convention on Biological Diversity and the Cartagena Protocol on Biosafety. China thus has to implement the obligations imposed by these two international instruments. China has not ratified the Nagoya-Kuala Lumpur Supplementary Protocol, although it participated in the negotiation of this supplementary protocol. Two reasons were explained as to why the obligations in the Nagoya-Kuala Lumpur Supplementary Protocol are discussed in this thesis while China has not ratified it. Firstly, an analysis of the Nagoya-Kuala Lumpur Supplementary Protocol is important to answer the question to what extent international liability rules aim to prevent and remediate environmental damage that may be caused by the cultivation of GM crops and related activities. Secondly, China might ratify the protocol in the foreseeable future. This thesis evaluated whether current liability rules in China already correspond with the liability rules as provided for by the Nagoya-Kuala Lumpur Supplementary Protocol.

Articles 10.6 and 11.8 in the Cartagena Protocol on Biosafety are operational provisions regarding the precautionary approach. It is an international obligation of China to implement the precautionary approach in legislation regarding the cultivation of GM 
crops and related activities. The provisions on the precautionary approach are abstract, giving parties the chance to implement this approach differently in their own domestic laws. Furthermore, the Cartagena Protocol on Biosafety sets requirements for access to environmental information related to GM crops and public participation in decision-making regarding GM crops. In contrast, the Cartagena Protocol on Biosafety does not regulate that the public has the right to enforce these rights before the court. The legal measures that have to be implemented by China in accordance with international law relating to GM crops include decision-making procedures regarding the importation and the domestic use of LMOs, risk management measures and liability and redress rules.

Chapter Three analysed the second main research question which was divided into two sub-questions: (a) What are sources of law and their scope regarding the prevention of environmental risks that may be caused by the cultivation of GM crops and related activities in China? (b) What is the institutional structure of this regulatory framework on GM crops in China? In particular, what are the administrative authorities that are responsible for the safe use of GM crops and how are these administrative authorities coordinated in China? China has established a regulatory framework regarding the safe use of GM crops. The prevention of environmental risks is included in the aims of each piece of legislation in this regulatory framework. The Regulations on the Administration of the Safety of Agricultural Genetically Modified Organisms is the central piece of legislation. Policies also play roles in addressing environmental risks that may be caused by cultivation of GM crops. The InterMinisterial Joint Conference for the Administration of the Safety of Agricultural Genetically Modified Organisms is responsible for the general supervision of GM crops and the coordination of the discussions about key issues. The Ministry of Agriculture, the Ministry of Environmental Protection and the General Administration of Quality Supervision, Inspection and Quarantine are key authorities in the prevention of environmental risks that may be caused by the cultivation of GM crops and related activities.

Chapter Four and Chapter Five analysed the third main research question. These two chapters focused on legal principles and legal measures, respectively. Chapter Four discussed: (a) What are the legal provisions that were enacted by China to implement the precautionary principle and the public involvement principle in order to deal with environmental risks that may be caused by the cultivation of GM crops and related activities? And (b) How has China implemented these two legal principles as provided for by the relevant international instruments regarding the prevention of environmental risks that may be caused by the cultivation of GM crops and related activities? This thesis identifies that the precautionary principle has not been adopted as a legal principle for the regulation of GM crops in China. However, this principle shares the same goal as the prudent approach declared by policy statements in China, which requires legislators and decision-makers to balance the risks and benefits of GM crops. As China has wide discretion in implementing the precautionary approach as required by the Cartagena Protocol on Biosafety, it is difficult to determine whether China is in breach of its international obligations in this regard.

There are several provisions which specify rights and obligations regarding public involvement relating to GM crops. Although the Cartagena Protocol on Biosafety does not explicitly require access to the court to enforce access to information, this possibility exists in China. Access to information and access to justice in environmental matters are better ensured than public participation in decision-making in China. Specific rules regarding public participation in decision-making are not stipulated regarding the regulation of GM crops. 
Chapter Five identified and analysed the legal measures in China that address environmental risks that may be caused by the cultivation of GM crops and related activities and explained whether, by implementing these legal measures, China has fulfilled its international obligations required by the Convention on Biological Diversity and the Cartagena Protocol on Biosafety and how China will possibly fulfil its potential international obligations in the Nagoya-Kuala Lumpur Supplementary Protocol. To cultivate GM crops and then put them on the market, biosafety certificates for GM crops shall be obtained, and producers of GM seeds shall have the licences for the production and business operations of GM seeds. Moreover, during and after cultivation, the competent administrative authority of agriculture has to supervise compliance with the law. After cultivation, if there is damage related to GM crops, measures such as liability rules shall be applied. These procedures are used by China to fulfil its general international obligations regarding the prevention of environmental risks that may be caused by the cultivation of GM crops and related activities. The decision-making procedures as provided for by the Cartagena Protocol on Biosafety are applicable to intentional transboundary movements of LMOs that may cause adverse effects to the conservation and sustainable use of biodiversity, taking into account risks to human health. Under the Cartagena Protocol on Biosafety, China has an obligation to have a legal framework regarding the advance informed agreement procedure for LMOs for intentional introduction to the environment. This legal framework applies to the first transboundary movements of LMOs for intentional introduction to the environment. Legal procedures for GM crops to be imported have been adopted and implemented in China. In addition, China has adopted legal rules regarding the importation of GM crops intended for research and GM crops in transit. In accordance with the Cartagena Protocol on Biosafety, parties have discretion regarding the legal measures that need to be taken to deal with the importation of GM crops for research and GM crops in transit. China can collect information regarding the use of GM crops during authorisation procedures. Information on the illegal cultivation of GM crops is a key component in this regard. Furthermore, the reporting mechanism and the inspection mechanism help the competent administrative departments of agriculture to get the full and latest information regarding the safe use of GM crops. In this vein, China fulfils the obligation to share information as prescribed in the Convention on Biological Diversity. The Nagoya-Kuala Lumpur Supplementary Protocol takes an administrative approach and a civil liability approach to ensure that response measures are taken by operators when environmental damage is caused by the use of GM crops. After examining the legal provisions regarding emergency measures, it was concluded that China can fulfil the obligation regarding the administrative approach as provided for by the Nagoya-Kuala Lumpur Supplementary Protocol.

Chapter Six summarised the main findings of this thesis and analysed the limitations and future research. It is observed that legal principles and legal measures as provided for in China's GMO legal framework have generally implemented the international obligations regarding the prevention of environmental risks that may be caused by the cultivation of GM crops and related activities. Future research may focus on the application and enforcement of the relevant Chinese legislation. It is also important to study how the environmental risks that may be caused by new techniques, such as genome-editing techniques, could be prevented, given the experience gained by regulating the cultivation of $\mathrm{GM}$ crops and related activities. 
